\title{
Normative foundations of the right to individual complaint in Turkey with a case study on electoral rights
}

\section{Ece Göztepe}

To cite this article: Ece Göztepe (2018) Normative foundations of the right to individual complaint in Turkey with a case study on electoral rights, Research and Policy on Turkey, 3:1, 68-89, DOI: 10.1080/23760818.2018.1445234

To link to this article: https://doi.org/10.1080/23760818.2018.1445234

曲 Published online: 18 Apr 2018.

Submit your article to this journal $\widetilde{ }$

Џ Article views: 20

View Crossmark data $\complement$ 


\title{
Normative foundations of the right to individual complaint in Turkey with a case study on electoral rights
}

\author{
Ece Göztepe* \\ Law School, Bilkent University, Ankara, Turkey
}

(Received 22 April 2017; accepted 14 December 2017)

\begin{abstract}
The constitutional amendment of 7 May 2010 established the right of individual complaint before the Constitutional Court of Turkey (CCT), which was further specified in the new Act on the CCT. The explanatory statement motivating the constitutional amendment explicitly referred to the huge amount of complaints against Turkey before the European Court of Human Rights. The article analyses the three main dimensions of the normative foundations of individual complaint and highlights its underlying structural problems. A case study of 18 CCT decisions on active and passive voting rights elaborates on two main problematic issues in this regard.
\end{abstract}

Keywords: Constitutional Court of Turkey; constitutional complaint; electoral rights; effective remedy; European Court of Human Rights

\section{Introduction}

Constitutional complaint proceedings as one of the most effective means of protection for fundamental rights have been the subject of comparative legal studies for a long while in Turkish legal literature. ${ }^{1}$ Yet resistance from high courts which feared that the Constitutional Court would be made into an ultimate court of appeal with this additional judicial competence impeded the introduction of this remedy over many years. In 2004, the Constitutional Court itself submitted a draft bill to Parliament compiled by an internal commission of judges. This triggered a new discussion prior to a comprehensive constitutional amendment in the same year. However, the bill was rejected by a parliamentary majority and could not be included in the comprehensive amendment. In the years that followed, this remedy was also included in the draft constitutional amendment put forward by the Union of Turkish Bar Associations ${ }^{2}$ and changed in certain details. However, it was only in 2010 that the will of the parliamentary majority was to align with that of many academics and the judiciary.

\footnotetext{
*Email: goztepe@bilkent.edu.tr

This article is an abridged and slightly amended version of my article published in German: "Die Einführung der Verfassungsbeschwerde in der Türkei - Eine Zwischenbilanz (2012-2014) [The Introduction of Constitutional Complaint in Turkey - Interim Results (2012-2014)], 63 Jahrbuch Des Öffentlichen Rechts, 2015, 485. The many judgments (about 450) delivered by the Constitutional Court and analysed in this article could not all be looked at in the English version due to limited space. For this English article, I have focused on a case study of the decisions relating to the Supreme Board of Election. I have selected these cases for their ability to reveal key basic problems with the new right of recourse.
} 
In order to be able to assess the function, objectives and weaknesses of the new system of legal protection, the constitutional and statutory bases must first be examined. Only on this basis will the analysis of the decisions of the Constitutional Court and an assessment of the efficacy of the new remedy be possible. The following will first set out the normative principles of constitutional complaint proceedings before going on to question, based on a case study of electoral rights, the decisions of the Constitutional Court in relation to the Supreme Board of Election and the potential of the new remedy to transform or impede the current system.

\section{Legal foundations}

The right to constitutional complaint was incorporated into the constitution with the constitutional amendment of 7 May 2010. ${ }^{3}$ Since the constitution regulated only the basic principles of the new competence of the Constitutional Court, the procedural elements and substantive law specifications were left to the Act on the Structure and Competence of the Constitutional Court (CCT Act). ${ }^{4}$ Further rules for the constitutional complaint are set down in the Rules of Procedure of the Constitutional Court (ByLaws). This three-level pyramid gives rise to significant questions with regard to conflict between legal norms.

The individual complaint was conceived as an extraordinary right of action which is only possible once all other ordinary courses of action in Turkey have been exhausted. In the preamble to the amending act, the reason for the introduction of this right of action was stipulated as the multitude of complaints against Turkey before the European Court of Human Rights (ECtHR). Indeed, together with Italy and Russia, Turkey is one of the frontrunners in terms of violations of the fundamental rights and freedoms contained in the European Convention for the Protection of Human Rights and Fundamental Freedoms (ECHR) and its protocols. It must also be added that the rights of the ECHR and its protocols at the base of the decisions of the ECtHR against Turkey are rights and freedoms for which a violation weighs especially heavily. ${ }^{5}$

It was hoped that the new extraordinary right of action would provide a means of recourse against violations of fundamental rights and freedoms within the national legal system, would save citizens the appeal to Strasbourg and avoid the massive compensations to be paid by the Turkish state due to frequent ECtHR judgments to its disadvantage. ${ }^{6}$ It must be added that the Committee of Ministers of the Council of Europe stressed the significance of the introduction of the individual complaint in its Recommendation No. 2004 (6) from 12 May 2004. ${ }^{7}$

The following sets out the substantive and procedural rules for the constitutional complaint from the level of the constitution all the way to court rules of procedure and discusses issues of conflict between the individual rules and the higher legal norm.

\subsection{The 1982 constitution (TC)}

Art. 148, which regulates the functions and powers of the Constitutional Court, was expanded after para. 2 to include three additional paragraphs and the principles of the constitutional complaint were set down. ${ }^{8}$ Turkish constitutional complaint proceedings limit themselves to the overlap in fundamental rights and freedoms guaranteed both by the constitution and the ECHR. Accordingly, not all fundamental rights and freedoms in the Turkish constitution can be examined by the Constitutional Court with regard to their constitutional interpretation and application in constitutional complaint proceedings. 
The new right of recourse has indeed extended the protection of fundamental rights and freedoms in the Turkish legal system, yet since not all fundamental rights and freedoms contained in the constitution can be the subject of an individual complaint, it can also be argued that there has been a downgrading of certain fundamental rights and freedoms. This primarily includes the fundamental social rights and freedoms contained in Art. 41 to Art. 65 TC which, strictly speaking, do not fall within the scope of this framework. In view of the jurisprudence of the ECtHR, it remains to be clarified whether and how far the settled case law of the ECtHR with respect to the close connection between negative fundamental rights and these social rights is to be taken into account in determining the scope of constitutional protection afforded through individual complaints. ${ }^{9}$ The Turkish Constitutional Court had itself affirmed the close connection between the right of corporeal and spiritual existence in Art. $17 \mathrm{TC}$ and the social rights, and interpreted the limits of the social and economic duties of the state pursuant to Art. 65 TC in this regard. ${ }^{10}$

Still today, Turkey has not ratified all supplementary protocols to the ECHR. The supplementary protocols (SP) nos. 4 and 12 have been signed by Turkey, though they have not yet been ratified. Such a situation gives rise to various legal problems and the catalogue of fundamental rights contained in the constitution is made subject to a graduated system of legal protection with the remedy of the constitutional complaint rendered inaccessible for several fundamental rights and freedoms. Some examples are: prohibition of imprisonment for debt (Art. 38 para. 8 TC / Art. 1 SP 4); prohibition of expulsion of nationals (Art. 23 para 6 TC / Art. 2 SP 4); equality between spouses (Art. 41 para. 1 TC / Art. 5 SP 7): and the general prohibition of discrimination independently of any further rights (Art. $10 \mathrm{TC} / \mathrm{SP} 12$ ), which is conceived in the constitution as a general principle. These cannot be asserted through constitutional complaint proceedings. The logical implication of this two-level approach would be to abolish the constitution's catalogue of fundamental rights in the long term and to consolidate the catalogue with a legally binding reference to the ECHR, which would not be desirable.

For this reason, the statutory framework of individual complaint proceedings is incredibly important, though amendments should also be made to other procedural laws in order to specify the criteria applied by the national courts of last instance with regard to fundamental rights and freedoms. This, however, has not yet occurred. ${ }^{11}$

In line with this new power, the structure and competence of the Constitutional Court had to be changed. ${ }^{12}$ Before the constitutional amendment in 2010, the Constitutional Court sat only in plenary session and did not have sections into which work was divided. Since 23 September 2012, the beginning of the power to hear individual complaints, the Constitutional Court ${ }^{13}$ has operated in two sections and as General Assembly. Individual complaints are heard by the sections (bölüm) with admissibility generally assessed by commissions (komisyon). Abstract and concrete judicial review proceedings, proceedings for the prohibition of a political party as well as proceedings in the capacity of Supreme Court are heard in plenary session. The sections are comprised of seven members and convene under the chairpersonship of a deputy president with at least four members. The president does not participate in the work of the sections. They take decisions on the substantive points of the application where admissibility has been examined by the commissions or on the admissibility of the application where the commission has referred this to the section ( $\S 3 \breve{\mathrm{g}}$ and 27 by-laws). For each section, three commissions are formed whose members rotate. As chairperson of the section, the deputy president is not a commission member. The commissions are responsible for determining the admissibility of 
the complaint and take decisions unanimously. If unanimity cannot be achieved, the case is referred to the sections ( $\$ 3 p$ and $32-33$ by-laws).

Last but not least, Art. 148 para. 4 TC should be mentioned which, on a literal reading, reflects a false understanding of the right to constitutional complaint. According to this, "in the individual application, judicial review shall not be made on matters required to be taken into account during the process of legal remedies". Considering that the constitutional complaint is conceived in Turkish law as an extraordinary right of action, only available after exhaustion of all other avenues of legal redress, it must be assumed that the fundamental rights complaint would already have been heard by ordinary courts. For this reason, the ordinary courts would necessarily have to deal with the assertion by the applicant that concrete application of the law also infringes his or her fundamental rights and freedoms. The subject of the application therefore limits itself before the Constitutional Court as here only arguments relating to fundamental rights may be made and other errors of substantive or procedural law must be dealt with in the respective manner and do not fall within the jurisdiction of the Constitutional Court.

It can be said then, that the Constitutional Court cannot review all issues which would fall to be assessed by the ordinary courts. In fact, the subject of the constitutional complaint only comprises a small subset of these issues. Indeed, the principle of subsidiarity requires that applicants assert the unconstitutional interpretation and application of the law in relation to their fundamental rights and freedoms before ordinary courts and to have this resolved there. This paragraph should ultimately be understood such that the Constitutional Court is not an ultimate court of appeal but rather, in collaboration with the ordinary courts, can only check the unconstitutional application of laws in relation to fundamental rights and freedoms as the final court of appeal and is not responsible for other legal errors in the application of ordinary law.

\subsection{Act No. 6216 on the Establishment and Rules of Procedure of the Constitutional Court (CCT Act)}

The tersely formulated Art. 148 para. 3 to 5 TC on the constitutional complaint was crystallized in 2011 with Act No. 6216 in $\$ 45$ to 51. It must be stated here that the legislator allowed itself plenty of room in setting out this right of action and, in areas, significantly limited the decisions of principle set down in the constitution. Even though the Constitutional Court has held the corresponding norms to be constitutional within the framework of abstract judicial review proceedings, ${ }^{14}$ the following looks at these limitations, respectively specifications. ${ }^{15}$

\subsubsection{The right of constitutional complaint}

Art. 148 para. 3 TC defines the scope of the fundamental rights and freedoms to be protected in the constitutional complaint as the overlap between the constitution and the ECHR. The supplementary protocols, which Turkey ratified after the ECHR, are not mentioned in the constitution. In view of the uniformity of the European system of protection of fundamental rights, the determination could also have been left to the Constitutional Court. It is to be welcomed that the legislator closed this gap with $\S 45(1)$. Indeed, $\$ 45(1)$ CCT provides that the overlap relates to the constitution and the ECHR with the supplementary protocols ratified by Turkey. This specification removes any uncertainty along with the risk of arbitrary application or non-application of the supplementary protocols. 
The constitution provides that all ordinary courses of action must first be exhausted before a constitutional complaint can be lodged. Thus, $\$ 45(2)$ explicitly includes "administrative remedies" (idari başvuru yolu) among these ordinary courses of action. Yet in Turkish law, the term "ordinary courses of action" covers only "judicial" remedies. In the law of civil procedure, these are appeal (temyiz) and rescission (karar düzeltme); in criminal procedure complaint (itiraz) and appeal; in administrative law complaint, appeal and rescission. These judicial remedies are processes, at the end of which a court judgment becomes substantively and/or formally binding or, as in the case of rescission, the judgment is reviewed by a court of the same instance in relation to the statutory grounds for rescission.

Neither the preamble to the Act nor discussions in Parliament throw light on which administrative remedies are intended. The application options (\$11) and application obligations before the responsible authority $(\S 13)$ set down in the rules of procedure for the administrative court (İdari Yargilama Usulü Kanunu) are requirements for a complaint and must be taken into account by the administrative courts ex officio. For this reason, it is unclear why the legislator extended the definition in this way. Whether, in the case of certain applications, the Constitutional Court will refer to a specific administrative authority and throw out the application citing the non-exhaustion of ordinary courses of action, remains to be seen.

Finally, attention should be drawn to a more serious statutory limitation of the right of constitutional complaint. Although the constitution refers to a right of action in the case of infringement by a "public authority", §45(3) CCT bars a constitutional complaint against a legislative act, regulatory administrative proceedings, the decisions of the Constitutional Court and against acts which the constitution itself places outside the scope of judicial control. It is beyond doubt that public authorities in relation to Art. 6 to $9 \mathrm{TC}$ include the legislature, executive and judiciary and all constitutional bodies in execution of their constitutional powers. Even if most constitutional complaints concern the judiciary owing to the requirement that ordinary courses of action first be exhausted, it cannot be excluded that the legislature or the executive violate a person's fundamental rights and freedoms through statute, executive act or legal ordinances with the force of law.

To protect fundamental rights, one could seek to claim the unconstitutionality of the legal norm on which the impugned court decision is based and thus set in motion a process of concrete constitutional review. Such an option was provided for in the draft in $\S 49(6)$ and allowed the sections to refer the provision on which judgment was based to the plenum during the assessment of the constitutional complaint. The objective was to protect fundamental rights and freedoms by way of concrete review of the statutory source of the violation of fundamental right. Yet this provision was struck from the draft by the constitutional sub-commission at the legislative stage, also with the votes of the opposition parties. The decision was justified on the basis of the unconstitutional extension of concrete constitutional review. ${ }^{16}$ It remains to be seen then whether the Constitutional Court will necessarily fall back on this in its jurisprudence, or whether it will see its power as limited through an historic interpretation of the CCT Act and refuse to take such a path altogether.

To continue, §45(3) CCT Act provides that "proceedings excluded from judicial review by the constitution pursuant to Constitutional Court judgments are not subject to individual application". Acts by public authorities, which are excluded from judicial review by the constitution, include decisions of the President which do not require cabinet approval (Art. 125 para. 2); the decisions of the Supreme Military Council with the 
exception of suspension from service, unless this relates to the retirement of personnel due to lack of posts or to promotion (Art. 125 para 2); the decisions of the Board of Judges and Prosecutors insofar as these do not relate to a suspension from service (Art. 159 para. 10); the decisions of the Supreme Board of Election (Art. 79 para. 2); as well as the decisions of tribunals against the decisions of sports clubs in relation to activities and discipline in sport (Art 59 para. 3). The question as to whether such constitutional norms limiting judicial review can be interpreted as usual even after the introduction of a new remedy will not be discussed further here. But this argument, amongst others, also crops up in the case study in Section 4.

\subsubsection{Capacity to lodge constitutional complaint}

According to the wording of the constitution, "everyone" can assert the breach of his or her fundamental rights before the Constitutional Court. The Turkish constitution makes no express reference to the standing of legal entities to assert fundamental rights. Accordingly, no constitutional relation to the standing of legal entities could be established. The all-encompassing description of the constitution has been specifically codified in statute and limited in areas. Complainants must first show three things. ${ }^{17}$ They must show that they are "presently, personally and directly" affected by the act - commission or omission - of the public body $(\S 46(1))$. Naturally, only Turkish nationals can assert the fundamental rights and freedoms which specifically apply to nationals. Foreigners can only assert general rights $(\S 46(3))$.

A restriction can be found in $\S 46(2)$. The section here provides that legal entities under public law do not have a right of constitutional complaint. On the other hand, legal entities under private law can only assert a breach of right where such a breach goes to their very essence. The categorical denial of standing to legal entities under public law to lodge a constitutional complaint could result in a gap in the protection for fundamental rights. As Turkey's administrative courts have repeatedly recognized, legal entities under public law can also enter into legal relations in which they do not appear as a representative of state, carry out public duties assigned by statute or, in some way, exercise sovereign power. In such private relationships, they would require the same procedural guarantees and must also be allowed to rely on procedural fundamental rights. Insofar as they do not have any special advantage in the legal relationship entered into, this would be a purely private relationship. Such a categorical denial of standing to legal entities under public law would, on the other hand, also impair the objective purpose of the constitutional complaint for the protection of the constitutional order. The Constitutional Court, however, has applied this legal principle very strictly and has not allowed any exception. ${ }^{18}$

\subsubsection{Requirements and assessment of admissibility}

Admissibility requirements are set down in $\S 45$ to $47(\S 48$ (1)). The Court has the power to reject applications which do not contribute to the application and interpretation of the constitution; which are irrelevant to the determination of the scope and limits of fundamental rights and freedom; which are manifestly unfounded; and in cases where the applicant has suffered no significant damage $(\$ 48(2))$. The constitutional complaint applications are assessed by the commissions with regard to their admissibility. The decision not to admit the application must be unanimous. If unanimity cannot be achieved, the application must be referred to the sections $(\S 48(3)(2)$ and (3)(3)). Deci- 
sions of non-admissibility are legally binding and the applicant must be notified in writing $(\S 48(4))$.

Over the past five years, points relating to admissibility requirements as well as substantive points have mainly been decided by the sections. The objective was to establish consistent precedent as guidance for the commissions for the subsequent years. On the Court's homepage, only 11 decisions from the commissions have been published.

\subsubsection{The Ministry of Justice as party to proceedings}

Pursuant to $\S 49(2)$, if the commission allows an application, a copy is to be forwarded to the Ministry of Justice for information purposes. The Ministry of Justice is authorized to submit an opinion on the application to the Constitutional Court where it believes such to be necessary. This rule raises many questions with regard to the function and the parties to constitutional complaint proceedings, and the reason and constitutionality of the rule must be questioned.

In the draft bill, it was proposed that a copy of the application was to be forwarded to the Ministry of Justice after the decision on admissibility by the commission. The justification for the paragraph was that the Ministry of Justice would be party to legal proceedings in Strasbourg and should have proper knowledge of any possible complaint before the ECtHR in order to defend the legal interests of the state. Yet during plenary discussions, a supplementary motion was submitted to have $\$ 49(2)$ extended to include a second sub-paragraph giving the Ministry of Justice the opportunity to submit its opinion on the application admitted to the Constitutional Court.

This addition is to question the nature and function of constitutional complaint proceedings. After all, the constitutional complaint is brought on the back of a violation of fundamental rights by public authorities and is conceived as a judicial check on those authorities. The proceedings recognize only the applicant as party. Like a claim for declaratory judgment issued before an administrative court, the proceedings can also be described as "declaratory proceedings" and are non-adversarial. Yet with the statutory opportunity for the Ministry of Justice to submit an opinion on the matter, the executive secures its influence on the jurisprudence. Since the participation of the executive is provided for by law and the Constitutional Court has no discretion in deciding whether to request the opinion, it is also not possible to view it as within the sphere of competence of the judiciary in the form of a legal report. This theory is supported by the fact that the power to commission reports as provided for in the draft bill in $\$ 49(3)$ was struck out by the sub-commission. Accordingly, it must be concluded that the principle of separation of powers as a general principle of the constitution set down in Art. 6 para. 3(2) in connection with Art. 9 TC is infringed as the executive is involved in the exercise of judicial authority by way of ordinary legislation.

\subsubsection{Interim measures}

Pursuant to $\$ 49(5)$, the sections have the power to impose interim measures during the assessment of the substantive points of the application either ex officio or on the application of the complainant "for the protection of the fundamental rights of the applicant". In the case of an interim measure, the substantive points of the application must be decided upon within six months. If the substantive issues are not decided within this period, the interim measures imposed are automatically revoked. 
With respect to this six-month period, in the draft bill, the "publication" of the decision on substantive issues was decisive, though the final version of the Act stipulated the "judgment date", irrespective of publication, to be decisive. This discrepancy between the two versions is due to the fact that the Turkish Constitutional Court does not publish the reasoning for its decision at the same time of the decision itself and in certain cases, in particular those involving key elements of socio-political issues, it first publishes only the tenor of the decision, posting the full judgment in the Official Gazette at a later date. According to Art. 153 para. 1 TC, nullity decisions may only be published once the reasoning has been submitted and only then do they take effect. Since the constitution provides in Art. 153 para. 6 TC that "the decisions of the Constitutional Court shall be immediately published in the Official Gazette", this practice cannot be described as constitutional in this respect.

In relation to constitutional complaint proceedings, the question is whether the rules as to the point in time in which these judgments become binding are also applicable to these proceedings. After all, Art. 153 TC only mentions nullity judgments, though the literature generally assumes that this also applies for other proceedings. With respect to additional constitutional rules, no exceptions with respect to binding force or the duty to publish were provided for constitutional complaint proceedings, yet pursuant to $\S 50(3)$ CCT Act, the decisions are notified to parties and the Ministry of Justice in writing and announced on the Court's homepage. The rule as to what judgments are to be published in the Official Gazette was left to the Court's rules of procedure.

Given such diverging constitutional and statutory rules, it can be concluded that the legislator focused primarily on the function of the constitutional complaint to protect fundamental rights and has extended the time period to the benefit of the applicant up to the judgment date and in so doing did not wish the delay in the publication of the Court's reasoning to fall to the applicant's disadvantage.

\subsubsection{The problem with violations based on an unconstitutional law}

According to $\S 49(6)$ of the draft bill, the sections had the power to refer a legal rule to the plenum to assess its constitutionality if, during the substantive assessment, they came to the view that the purported breach was based on an unconstitutional law or an unconstitutional ordinance with the force of law. This rule was struck out by the preparatory Constitutional Commission and was not re-included in the Act in the plenary discussion. Criticism by commission members focused first, on the fact that this power afforded to the sections would create a new avenue of concrete judicial review which was not provided for in the constitution, and secondly, on the fact that the Constitutional Court would act both as judge as well as complainant on the matter. Half of the plenum, after all, would be comprised of the members of the respective section which had submitted the application for an assessment of constitutionality. Accordingly, they would already have announced their opinion in the legal matter at hand. ${ }^{19}$

This criticism of Members of Parliament is not in line with consistent case law of the Constitutional Court, nor is it in line with the function of constitutional complaint proceedings. The Constitutional Court understands itself in its settled case law as a "court" in the sense of Art. 152 para $1 \mathrm{TC}^{20}$ in proceedings for the prohibition of a political party ${ }^{21}$ or proceedings in the capacity of Supreme Court. Since the Constitutional Court in both these proceedings passes judgment in the first and final instance and the essence of the proceedings do not correspond to judicial review, the criteria accepted in settled case law can, in my opinion, be applied mutatis mutandis to constitu- 
tional complaint proceedings. After all, these proceedings are primarily a matter of ensuring the constitutional interpretation and application of the law in relation to fundamental rights and freedoms, but also about guaranteeing the constitutional legal order. To deny this power to the sections means that the application for an assessment of the constitutionality of laws on whose application a purported violation rests must again be brought before the Constitutional Court in a long and indirect route. If the sections were to determine a breach of fundamental right on the basis of an unconstitutional law, they would only be able to state this in their judgment and in referring the case back to the trial court point out the unconstitutionality of the law on which the decision is based. In assessing its own decision, the trial court would then, pursuant to Art. 152 para. 1 TC, only have the option of presenting the question of constitutionality to the Constitutional Court. It is obvious that such a long and indirect route cannot serve the protection of the constitutional order. For this reason, it remains to be seen whether the Constitutional Court, without taking account of the historic interpretation of the CCT Act, will assert such a power or not.

\subsubsection{The decisions}

After examining the substantive issues, the breach of fundamental rights and freedoms can either be found or the complaint rejected. In the case of a successful constitutional complaint, the Constitutional Court must also determine in its judgment the means by which the violation of right itself and its consequences are to be reversed (§50(1)). If the violation of right is due to a court judgment, the legal act is referred back to the competent court for retrial. If the Constitutional Court sees no legal benefit to a retrial, it can set damages for the complainant or refer to possible actions before trial courts. At the retrial, the court is bound to remedy the violation of right and its consequences in its decision $(\$ 50(2))$.

The statute does not state the possibilities available to the Constitutional Court where the violation of right is based not on commission but on an omission by a public body. In $\S 50(3)$, the draft bill gave the Constitutional Court the power to determine which public body is to remedy the consequences of the omission and, in certain cases, also to determine the form of the measures. This rule was not accepted at Parliament's plenary sitting. Especially with respect to violations due to excessively long duration of proceedings or unlawfully long custody periods, it is particularly important how and when the consequences can be remedied. In its five-year history, the Constitutional Court has limited itself to award damages to the complainant in such cases and to refer the legal act back to the trial court to remedy the legal consequences of the omission by the public body. ${ }^{22}$ The Court has held back from answering the question as to whether a prisoner is to be immediately released.

The wording of the law on the remedy of consequences of violations determined by the Constitutional Court has also undergone fundamental changes through the legislative process. In order to avoid the criticism from the appeal courts that the constitutional complaint will elevate the Constitutional Court to an ultimate court of appeal, the provision for a second appeal to the Constitutional Court by the complainant was not accepted by the plenum. The draft version provided that "the complainant can appeal again to the Constitutional Court, if the trial court decision is not in line with the finding of the Constitutional Court". In this case, the Constitutional Court itself should decide on the substantive issue and rectify the consequences of the violation. The elimination of this provision is to be welcomed as it would indeed mean the Constitutional 
Court sitting as ultimate court of appeal in substantive points of law and the lower courts would be deprived of their discretion in eliminating legal consequences.

\subsection{The rules of procedure of the Constitutional Court (by-laws)}

Section 5 of the CCT Act provides that the Constitutional Court set down its own rules of procedure, resolved in plenum (s. 1) and which must be published in the Official Gazette (s. 2). The Constitutional Court fulfilled this duty 15 months after the entry into force of the new CCT Act on 12 July 2012. On 5 March 2014, a range of amendments with respect to the provisions on the constitutional complaint were enacted which immediately after their publication in the Official Gazette were applied in cases of great societal and political significance (Twitter ${ }^{23}$ and YouTube ban ${ }^{24}$, the so-called Sledgehammer case (Balyoz davasi) ${ }^{25}$ against high-ranking officers, freedom of speech of Abdullah Öcalan, ${ }^{26}$ the imprisoned leader of the Kurdistan Workers' Party (PKK), and the headscarf ban for solicitors ${ }^{27}$ ).

On closer examination of the provisions of the rules of procedure, it becomes clear that the Constitutional Court has allowed itself substantial room for discretion in substantive and procedural specification of the new remedy, beyond the framework of the Act. In order to give adequate consideration to these provisions, which go beyond the framework of the Act, the first version of the rules of procedure will be briefly explained. Parallel to this, the amendments from 5 March 2014 and the background to these amendments will be explained in order to better understand the current state of the law.

\subsubsection{The extension of the powers of the plenum through the by-laws}

In the new court structure, the Constitutional Court works in two sections (bölüm) in constitutional complaint proceedings and in all other proceedings in plenum (genel kurul). The plenum is comprised of 17 members and sits under the chairpersonship of the president or of a deputy president determined by the president. The plenum is quorate when at least 12 members are present (Art. 149 para. $1 \mathrm{TC}$; $21 \mathrm{CCT}$ Act). The decisions are generally taken ${ }^{28}$ with absolute majority. In the event of equal votes, the president shall have the casting vote $(\$ 65(1)$ CCT Act).

The constitution also specifies in Art. 149 para. 2 the division of labour between the responsible bodies of the Court and provides that constitutional complaint proceedings are decided by the sections ( bölüm). Statute also ascribes the plenum the task of organiz ing and coordinating the division of labour between the sections in order to avoid an unequal workload between the sections ( $\$ 21 \mathrm{~d}$ and e). Neither the constitution nor ordinary legislation sets down the power of the plenum to intervene in constitutional complaint proceedings, respectively to decide on applications. The law also provides that commissions are to be established in order to decide on admissibility and that their structure is to be set down in the rules of procedure (Art. $2 \mathrm{~g}$ and $\$ 22(2) \mathrm{CCT}$ Act).

In the first version of the rules of procedure, the presiding judge was allocated the task of "summoning the plenum to discuss the situation where there is a conflict in the jurisprudence of the sections or where such could arise" $(\S 10,1)$. The consequence of summoning the plenum was further specified in $\$ 25(\mathrm{~d})$ and the plenum accorded the power of "deciding on the contradictory jurisprudence of the section". In view of the clear constitutional rule that in constitutional complaint proceedings only the sections are responsible and that the plenum decides on all other proceedings, it can be stated 
that the provision in the rules of procedure which allocates one body of the Court a power not foreseen in the constitution or in statute therefore stands in conflict with the two higher legal norms.

As a result of the amendment from 5 March 2014, the power of the plenum was expanded and it was stipulated that the plenum may "decide on constitutional complaint proceedings which are referred to it from the sections" ( $\$ 26$ in conjunction with $\S 10,1)$. The plenum is therefore not only the ultimate authority in harmonizing the jurisprudence of the sections, but can also decide on the substantive case in hand. With what intention, respectively for what reason the Constitutional Court believed such an extension of power be necessary, cannot be objectively determined. Yet in view of the cases decided by the plenum shortly after the amendments entered into force, it is to be presumed that in high-profile cases of societal and political importance, the Court did not want to leave the responsibility for legal consequences on the shoulders of the sections and that the Court wished instead to pass judgment in plenary session. Since the Constitutional Court president can only exert influence on the decisions where these are taken in plenary session, this also expands his sphere of influence. Despite the good intentions of the Court, it must be stated that the examined provisions of the rules of procedure are unconstitutional and unlawful.

\subsubsection{Proceedings without a referral to the Ministry of Justice for its opinion (expedited proceedings)}

Notification of the Ministry of Justice in respect of applications admitted for decision as well as the opportunity for the Ministry to submit an opinion on the application $(\S 49(5)$ CCT Act) were time limited in the first version of the rules of procedure ( $\$ 71$ by-laws). The standard period for the submission of an opinion stood at 30 days. On application by the Ministry, the period could be extended by a further 30 days. If the Ministry failed to submit an opinion within the allotted period, the Court was to continue with the available documents and deliver its judgment on that basis.

The amendment from 5 March 2014 provides firstly that the period can be extended by up to 30 days and that the application will not be decided upon by the Court, that is the section, but by the presiding judge, who is one of the deputy presidents. The opportunity for the Ministry of Justice to submit an opinion is therefore not completely limited, but by accelerating the decision by the presiding judge of the section, it is relatively limited.

The main novelty of the amendment is that the Court can now itself decide whether the Ministry of Justice is to be indirectly excluded from the decision process or not. Pursuant to the new version of $\S 71(2)$ by-laws:

when settled case law is available with respect to the substantive issue or where an urgent decision is required in the case, the Court can decide on the admissibility of the application and on the substantive issues itself without waiting for an opinion to be submitted by the Ministry of Justice.

In this case, the Court has to make this decision and not the presiding judge of the section. This allows the Court to adjudicate on the case in expedited proceedings and to waive the opinion of the Ministry of Justice. The Ministry of Justice must still be notified of the admission of the application, but it would only be able to become involved in the case during possible proceedings before the ECtHR. ${ }^{29}$ After the amendment to the by-laws, the scope for the submission of opinions by the Ministry of Justice has 
been considerably reduced and it is not rare that the Ministry does not submit an opinion at all.

\subsubsection{Limitation of the requirements for interim measures through by-laws}

Pursuant to $\$ 49(5)$ CCT Act, the sections have the power to impose interim measures during the assessment of the substantive points of the application either ex officio or on the application of the complainant "for the protection of the fundamental rights of the applicant". Where an interim measure is issued, the substantive points of the application must be decided upon within six months. If not, the measures are automatically revoked. The grounds of an interim measure are formulated in very general terms so that the Court has further room for discretion. On the other hand, the imposition of such measures is only possible once the commission has decided to admit the application so that in very urgent cases, the main burden falls on the commission to decide on admissibility as quickly as possible. If not, the commissions have no means of taking the necessary measures. The decision on the issue of an interim measure does not require a qualified majority.

The provision of the rules of procedure (\$73(1)) limits the wording of the Act considerably by requiring a "serious risk to life or to material or spiritual integrity" of the applicant before an interim measure can be granted. This is to impose a considerable limit on the scope of the fundamental rights to be protected and to reduce the range of measures - the necessity of which cannot be immediately fully appreciated - to a mere fraction. ${ }^{30}$

On the other hand, paragraph 4 grants the Court the power to decide on the extension of the period of validity of the interim measure, although the six-month period for judgment on substantive points still applies. With the option of extension, both of the impact of the interim measure and of the period for decision on the substantive issues, the limits on the Act are extended; limits which go clearly beyond the intent and purpose of the Act. Although the provisions of the rules of procedure are more in line with the security function of interim measures to ensure legal protection than the statutory provisions, the tendency of the Court to expand its powers is also to be challenged in this case.

Pursuant to $\$ 73(4)$ by-laws, the measures imposed by interim measure were revoked automatically where no decision was taken to extend them, the application rejected or where it was decided that the application had been forfeited.

\subsubsection{The selection of judgments for publication in the Official Gazette}

Pursuant to $\S 50(3)$ CCT Act, the decisions of the sections are notified to parties and the Ministry of Justice in writing and published on the Court's homepage. The rule as to which decisions are also to be published in the Official Gazette is left to the Court's rules of procedure. Pursuant to $\$ 81(5)$ by-laws, decisions which have pilot judgment character (in the sense of $\S 61$ of the rules of the procedure of the ECtHR) or which are significant in the development of case law shall be published in the Official Gazette. The decision in this regard shall be made by the presiding judge of the respective section. $^{31}$ 


\section{Further legislation accompanying the constitutional complaint proceedings}

Since ratifying the ECHR on 18 May 1954, Turkey has enacted several human rights statutes, founded institutions for the protection of fundamental rights and freedoms and formed a corresponding expert commission at the parliamentary level. The Act "for the settlement of applications lodged with the ECtHR by compensation payment" (No. 6384) is of particular importance within the framework of constitutional complaint proceedings since the ECtHR has also used this Act to reduce the number of applications from Turkey and, immediately after the creation of this new power of the Constitutional Court, has referred complainants from Turkey to this new domestic right of recourse.

This Act aims to settle certain applications pending before the ECtHR through the payment of compensation through domestic proceedings. The areas of law covered by the Act include criminal (investigation and prosecution), civil and administrative proceedings which were not concluded within a reasonable period or where court judg ments were enforced late, partially or not at all (\$2(1)). Upon recommendation from the Ministry of Justice, the Council of Ministers may extend these areas of law in view of the settled case law of the ECtHR in relation to Turkey $(\$ 2(2))$. For the purposes of determining the compensation sum, a five-member commission has been established comprising four judges seconded to the Ministry of Justice as well as a civil servant from the Ministry of Finance ( $\$ 4)$.

Complainants whose applications are pending before the ECtHR up to 23 September 2012 had the option of turning to the commission within six months after the Act entered into force. If this deadline was missed, they could assert their claims before the commission within one month of the inadmissibility decision of the ECtHR where this was based exclusively on the non-exhaustion of domestic rights of recourse (§5). The commission must decide on the application within a period of nine months and must take account of the jurisprudence of the ECtHR. Appeal can be lodged against the decision of the commission at the Regional Administrative Court of Ankara with the decision on the appeal to be reached within three months. The Court can set another compensation sum; the corresponding decision is final and no remedy is available ( $\$ 7)$.

Roughly a year after the Act entered into force, on 16 March 2014, the Council of Ministers extended the time frame as well as the legal areas covered. Accordingly, complaints which are pending before the ECtHR on 23 March 2013 fall within the jurisdiction of the commission if the subject of complaint is:

- the significant loss in value on payment of compensation for expropriation due to the duration of proceedings and inflation;

- the limitation of the rights of defence of detained or imprisoned persons in respect of disciplinary measures;

- the limitation of freedom of communication in penal institutions due to the prohibition of languages other than Turkish;

- the limitation of freedom of communication in penal institutions due to the nonpostage of letters due to the prohibition of languages other than Turkish; as well as

- the limitation of access to newspapers in penal institutions $(\$ 4, \mathrm{a}-\mathrm{d}) .^{32}$

Already before the introduction of the constitutional complaint in Turkey, the ECtHR drew attention to the need for a domestic solution in the case of violation of $\S 6$ para. 1 ECHR due to excessive duration of proceedings and absence of remedy through 
pilot proceedings pursuant to Art. 61 of the rules of procedure and recommendations of the Committee of Ministers. ${ }^{33}$ The ECtHR compelled Turkey to introduce effective legal protection in cases with long duration of proceedings within one year of the specific case becoming res judicata. ${ }^{34}$

The expectation of Turkey to establish effective legal protection against the structure and system-related problem of long duration of proceedings gave rise to Act No. 6384 mentioned above. The first judgment of the ECtHR evaluating the Act and the timeframe for its application was delivered two months after its entry into force on 26 March 2013. ${ }^{35}$ The ECHR held that in view of the high number of impending complaints due to the excessive duration of proceedings and the application of pilot judg ment proceedings in Ümmühan Kaplan vs. Turkey, when determining admissibility and the question of whether all domestic remedies had been exhausted, it would be necessary in the specific case at hand to deviate from the general rule. Accordingly, the Court held that the date of application to the ECtHR should not be the yardstick for the admissibility assessment, but rather complainants should be referred to the new right of recourse in Turkish law, even if their applications were submitted to the ECtHR before entry into force of the law allowing the payment of compensation. The key date of 23 September 2012 gave Turkey the opportunity to prove both the efficacy of the Act as well as that of the constitutional complaint proceedings. ${ }^{36}$

\section{Case study on the decisions of the Constitutional Court on the judicial protection of election rights}

The Turkish Constitutional Court has delivered judgments in several key cases of sociopolitical importance since 23 September 2012 which have drawn attention and praise not only from academic circles but from the wider public too. The main decisions to be mentioned here are: Twitter, YouTube, Öcalan and DTP judgments on freedom of speech $^{37}$; the civil liberties and rights of representation of imprisoned representatives ${ }^{38}$; trade union rights ${ }^{39}$; the right to life and the absolute prohibition on torture ${ }^{40}$; right to privacy and respect for private life ${ }^{41}$; right to property ${ }^{42}$; and protective judgments and judgments which actively apply the principle of proportionality. ${ }^{43}$ Yet within the framework of this article, a range of decisions on voting rights have been selected as case studies. These cases have been chosen because of the two problems they pose, namely overlap and their subject matter, which allow constitutional complaint proceedings to be analysed and structural weakness of current jurisprudence to be illustrated.

As already mentioned (Section 2.2.1 above), the Constitution contains several clauses which limit the judicial review of administrative acts with very different choices of wording. In Art. 59 para. 3, 125 para. 2 and 159 para. 10 this is expressed as follows: "are final decisions and shall not be appealed to any judicial authority", "are outside the scope of judicial review" or "shall not be subject to judicial review", respectively.

The provisions with respect to the Supreme Board of Election (Yüksek Seçim Kurulu) are peculiar with respect to the wording chosen by the legislator as well as the special position of the Supreme Board of Election in relation to the exercise of electoral rights. Art. 79 TC states that:

(1) Elections shall be held under the general administration and supervision of the judicial organs; 
(2) (As amended on October 21, 2007; Act No. 5678) The Supreme Board of Election shall execute all the functions to ensure the fair and orderly conduct of elections from the beginning to the end, carry out investigations and take final decisions, during and after the elections, on all irregularities, complaints and objections concerning the electoral matters, and receive the electoral records of the members of the Grand National Assembly of Turkey and presidential election. No appeal shall be made to any authority against the decisions of the Supreme Board of Election; [...]

(3) (As amended on October 21, 2007; Act No. 5678) The general conduct and supervision of a referendum on laws amending the Constitution and of election of the President of the Republic by people shall be subject to the same provisions relating to the election of deputies.

The last sentence of para. 2 that "No appeal shall be made to any authority against the decisions of the Supreme Board of Election" is of special importance in view of the judicial function ${ }^{44}$ of the Supreme Board of Election. The Board has to guide and supervise general and regional elections as well as the presidential election, so it plays a key role in the protection of active and passive voting rights. The Election Act No. 298 from 26 April 1961 also provides for provincial and municipal election boards which are subordinate to the Supreme Board of Election. Yet even some decisions of the municipal boards of election are final without the influence of the Supreme Board of Election (§55/A (5); 111(2)).

The Constitutional Court allowed itself a lot of time in answering the question as to whether the decisions of the Supreme Board of Election can be the subject of a constitutional complaint as the Court first had to clarify its previous case law on the judicative function of the boards of election. The jurisprudence of the Court within the framework of concrete judicial review revealed certain contradictions through its development. Whereas the Court still recognized the Supreme Board of Election in $1969^{45}$ as a "court", in $1992^{46}$ it rejected the judicative character both of the provincial boards of election as well as of the Supreme Board of Election. In its first decision within the framework of the constitutional complaint, after a period of 22 years, the Constitutional Court looked at the question again and came to a different conclusion. Following the jurisprudence of the ECtHR on the term "tribunal", ${ }^{47}$ the Court came to the conclusion that the provincial boards of election also exercise a judicative function and must so be considered as courts. ${ }^{48}$ The criteria applied by the Court could without further ado also be applied to the Supreme Board of Election so that constitutional complaints can also be lodged against the final decisions of the Supreme Board of Election. Yet the Court avoided in this specific case from answering this still open question. ${ }^{49}$

The constitutional complaints which ensued related to voting rights at a regional level. In particular, the application of candidate Mansur Yavaş from the opposition party CHP (Republican People's Party) due to election fraud in regional elections in Ankara is of particular significance. It basically fell to the Court to determine whether the right to vote in regional elections came within the scope of the new right of recourse. The Court decided on an interpretation which limited the constitutional protection for the right to vote, despite the guarantees in the constitution (Art. 67, 79 and 127) not to differentiate between general and regional elections and to defend election guarantees at all levels.

In its decision, the Court held that in constitutional complaint proceedings pursuant to Art. 148 para. $3 \mathrm{TC}$ and $\S 45(1) \mathrm{CCT}$ Act, only "fundamental rights and freedoms 
secured under the Constitution which fall into the scope of the European Convention on Human Rights and supplementary protocols thereto" can be asserted. However, since Art. 3 of the first protocol to the ECHR only commits the contracting parties to hold free elections for "the choice of the legislature", regional elections do not fall under the scope of the protocol and are therefore outside the scope of application of the constitutional complaint. ${ }^{50}$

The Court has also perpetuated its restrictive jurisdiction in a constitutional complaint case against the referendum on crucial constitutional amendments held on 17 April 2017, so that referenda would not fall under the scope of the ECHR and the constitution, and logically could not be scrutinized by the CCT. ${ }^{51}$ With this limitation, the Court excluded a large section of the political workings in Turkey from the protection of the new right of recourse. In addition, the constitutional guarantees on the right to vote and the principles contained in the constitution were diminished and excluded from judicial protection.

This restrictive case law was consolidated in relation to presidential elections as well. In two judgments, ${ }^{52}$ the Court held that presidential elections also fell outside the scope of the first protocol and thus could not be the subject of a constitutional complaint. Despite Art. 79 para. $6 \mathrm{TC}$ which states that "the general conduct and supervision [...] of election of the President of the Republic by people shall be subject to the same provisions relating to the election of deputies", the Court held that it could not be called upon in the case of a violation of the principles on the right to vote. In view of further decisions relating to the presidential election and decisions rejected on the grounds that applicants do not have standing, ${ }^{53}$ as the complainants were not affected personally, presently and directly by the impugned acts, it is clear that only the right to vote in general elections remains within the scope of the constitutional complaint. Without a doubt, these decisions represent an unconditional and unconstitutional subsumption of the Turkish constitution under the ECHR and a relinquishment of part of the constitution as yardstick for the constitutional complaint.

A further aspect with regard to the protection of political fundamental rights is found in the application of three political parties not represented in Parliament challenging the $10 \%$ threshold in general elections. The applicants turned to the Constitutional Court as "potentially affected parties" under the statutory rule with regard to the impending elections on 7 June 2015. They asserted a violation of their voting rights on account of the threshold being disproportionately high and thereby contrary to the principles of equality and of fair representation. The Court rejected the claim with a short and very formal explanation that the application for the repeal of legislation and pursuant to $\S 45(3) \mathrm{CCT}$ Act is not admissible. ${ }^{54}$ The Court did not respond to the term "potentially affected parties" and its circumstances of application.

The excellent dissenting opinion of Justice Erdal Tercan was apparently not able to change the minds of the majority of the judges. In his judgment, Justice Tercan focuses on a peculiarity of the statutory provisions and shows meticulously why in their case no administrative act is required for them to operate in such a way as to violate the right to vote, as is normally the case for general legislation. In contrast to the case for general legislation, the application and impact of the relevant legal provisions went hand in hand and there is no administrative act against which legal action can be taken. The majority opinion would remove constitutional protection from voting rights, he went on, as since the Supreme Board of Election also provides no protection, this would be tantamount to removing a fundamental right from the constitution. 
The last two decisions ${ }^{55}$ complete the circle in the discussion of the protection of the active and passive right to vote by the Constitutional Court and whether the decisions of the Supreme Board of Election in constitutional complaint proceedings can be the subject of assessment. In both decisions, the Court had to deal with Art. 79 para. 2 ("No appeal shall be made to any authority against the decisions of the Supreme Board of Election") and interpret its meaning. The Court decided on a very formal and restrictive line of argumentation and held that constitutional legislators intended the decisions of the Supreme Board of Election to be final and unchallengeable and that the Constitutional Court was also included in the expression "any authority". 56

As in the previous case, here too the three dissenting judgments shine with their argumentative and substantial force. The arguments can be summarized as follows:

(1) There is no doubt that the decisions of the Supreme Board of Election as a judicative organ on the right to vote are final. The constitutional provisions reinforce in this regard only the finding that these decisions are not administrative acts;

(2) However, it does not follow from this that the constitution has placed these decisions beyond all judicial scrutiny. As an extraordinary remedy, the constitutional complaint can only be brought against legally binding final court judgments, which is also the case for the decisions of the High Court of Appeal, Council of State, High Military Court of Appeal as well as the High Military Administrative Court (Art. 154-157 TC), as they too are "last instance(s) for reviewing decisions and judgments". After the introduction of the constitutional complaint, last instance decisions from exactly these courts have been the subject of constitutional complaints;

(3) The literal and historical methods of interpretation also require such an understanding of Art. 79 para. 2 TC, as the constitutional amendment of 2010 and the introduction of the constitutional complaint changed the absolute character of the last instance decisions of the high courts which must now be seen in the light of the new right of recourse. Even the decisions of the Supreme Board of Election as last instance court judgments can therefore be appealed before the Constitutional Court where these were to violate a fundamental right;

(4) The direct consequence of the majority opinion is that active and passive voting rights are removed from the protection and jurisdiction of the Constitutional Court. This contradicts the intent and purpose of the constitutional complaint and as a result not only the right to vote is undermined, but also the election boards must do without the help of the Constitutional Court in interpreting statutory provisions.

In summary, it can be said that the CCT has left itself a lot of time in answering the question as to how far the active and passive right to vote can be enforced through the constitutional complaint and whether a constitutional complaint is possible with regard to the decisions of the Supreme Board of Election. Even if the basic lines of the case law could have been determined with the first applications in the form of an obiter dictum, the CCT consciously chose not to do this. It has preferred to establish its case law chronologically on a case-by-case basis with regard to the scope of the constitutionally protected right to vote irrespective of the level of election (overlap issue), with regard to standing and on the question of the subject of complaint. On 7 October 2015, the circle of open questions was completed. Yet the analysis of the decisions shows that the CCT 
has created a body of case law which severely limits the constitutional protection for the right to vote, referring only to the minimal protection of the ECHR and thus falling substantially short with regard to the intent and purpose of the constitutional complaint.

\section{Conclusion and outlook}

Turkish constitutional complaint proceedings were introduced with the political intention of reducing the number of applications before the European Court of Human Rights and reinforcing protection for fundamental rights at the national level. Yet the absolute orientation on the ECHR and the jurisprudence of the ECtHR does not always offer citizens in Turkey broad legal protection, indeed the broader constitutional guarantees of the Turkish constitution relative to those of the ECHR are not being taken into account by the Constitutional Court. Both the normative orientation on the overlap between the ECHR and the Turkish constitution as well as the non-consideration of the provisions extending fundamental rights and freedoms in the constitution devalue some constitutional guarantees of legal protection and at the same time violate Art. 53 ECHR. As long as the Constitutional Court does not view the constitutional complaint as a national remedy for the reinforcement of fundamental rights and freedoms, and only as an intermediate stop on the threshold to European protection of fundamental rights, this remedy will be unable to fulfil its actual function.

The jurisprudence of the Constitutional Court on constitutional complaint proceedings can generally be seen as positive as the Court is grappling ever more intensively with the catalogue of fundamental rights under the Turkish constitution. Up to now, the Court has satisfied itself in abstract and concrete judicial review proceedings with the principles of the Republic set down in Art. 2 TC and has largely excluded the catalogue of fundamental rights from its standards of review. It remains to be hoped that the Court's approach to fundamental rights in the new remedy will have an impact on other types of proceedings.

It also remains to be seen whether the individual complaint will actually have the desired effect in relation to applications before the European Court of Human Rights. Only when rejected applications are lodged before the ECtHR and decided there will it be possible to determine at a European level whether the Turkish individual complaint represents an effective domestic right of recourse for the protection of fundamental rights and freedoms or not.

\section{Disclosure statement}

No potential conflict of interest was reported by the author.

\section{Notes}

1. See Armağan (1971); Gören (1994); Göztepe (1998); Pekcanıtez (1995); Sabuncu (1984); Sabuncu (1982).

2. Türkiye Barolar Birliği (2007, Art. 166).

3. The Constitutional Amendment Act No. 5982 was enacted by Parliament on 7 May 2010. Since the President submitted the law to a referendum pursuant to Art. $175 \mathrm{TC}$, the changes did not enter into force until 23 September 2010 after publication of the official results of the referendum from 12 September 2010. See Official Gazette from 23 September 2010, No. 27708. For an analysis of this constitutional amendment process see Göztepe (2010) and for 
an English translation see https://global.tbmm.gov.tr/docs/constitution_en.pdf (last accessed October 6, 2017).

4. For the English translation see http://www.venice.coe.int/webforms/documents/?pdf=CDLREF(2011)047-e (last accessed October 6, 2017).

5. Cf. Statistics of the ECtHR for the period 1959-2016, http://www.echr.coe.int/Documents/ Stats_violation_1959_2016_ENG.pdf (last accessed October 6, 2017). According to these statistics, 3270 cases were decided against Turkey in this period and in 2889 cases a violation of at least one fundamental right was found. Such high numbers in relation to the breach of fundamental rights and freedoms paint a poor picture of the state of the rule of law in Turkey. This affects the following areas in particular: the right to life and the lack of effective investigation (Art. 2 ECHR) (337); prohibition of torture and the lack of effective investigation (Art. 3) (553); right to liberty and security (Art. 5); right to a fair trial, long duration of proceedings and non-implementation of court judgments (Art. 6) (2186); freedom of expression (Art. 10) (265); right to an effective remedy (Art. 13) (268); and protection of property (Art. 1 Protocol to ECHR) (653).

6. For the reasons behind the new right of action, see "Adalet ve Kalkınma Partisi Grup Başkanı İstanbul Milletvekili Recep Tayyip Erdoğan ve 264 Milletvekilinin”, 16, 18-19.

7. Recommendation $\operatorname{Rec}(2004) 6$ of the Committee of Ministers to member states on the improvement of domestic remedies (adopted by the Committee of Ministers on 12 May 2004). See, in particular, points 10 and 22.

8. Art. 148 TC: (3): "Everyone may apply to the Constitutional Court on the grounds that one of the fundamental rights and freedoms within the scope of the European Convention on Human Rights which are guaranteed by the constitution has been violated by public authorities. In order to make an application, ordinary legal remedies must be exhausted.(4) In the individual application, judicial review shall not be made on matters required to be taken into account during the process of legal remedies. (5) Procedures and principles concerning the individual application shall be regulated by law". For an English translation of the Turkish constitution see: https://global.tbmm.gov.tr/docs/constitution_en.pdf (last accessed October 6, 2017).

9. With respect to the jurisprudence of the ECtHR in relation to fundamental rights and freedoms and their connection with social rights, see: Feldbrugge vs. the Netherlands, No. 8562/ 79 (29.5.1986); Airey vs. Ireland, No. 6289/73 (9.10.1979); Sidabras and Dziautas vs. Lithuania, No. 55480/00 and 59330/00 (27.7.2004); N. vs. The United Kingdom, No. 26565/05 (28.5.2008); Salesi vs. Italy, No. $13023 / 87$ (26.2.1993); Guerra and Others vs. Italy, No. 116/1996/735/932 (19.2.1998).

10. See the decisions from 17.1.1991, E. 1990/27, K. 1991/2 and from 16.10.1996, E. 1996/17, K. 1996/38. The Constitutional Court held in both concrete judicial review proceedings that the payment of treatment costs for chronically ill patients must not be limited to 18 months where, at the end of this treatment period, the disease has not been cured. Here, the Court reasoned that to suspend treatment in these cases would violate the right to life. The limits of the welfare state are regulated at the end of the section "The extent of social and economic duties of the State" in Art. 65 TC as follows: "The State shall fulfil its duties as laid down in the constitution in the social and economic fields within the capacity of its financial resources, taking into consideration the priorities appropriate with the aims of these duties.'

11. With regard to the exhaustion of remedies in relation to the individual complaint, see Schilling (2010, 301, para. 698); Grabenwarter (2009, 58, para. 23 et seq.).

12. New version of Art. 149 para. 1 TC: "The Constitutional Court consists of two sections and the General Assembly. The sections convene under the chairpersonship of the deputy president with the participation of four members. The General Assembly shall convene with the participation of at least twelve members under the chairpersonship of the President of the Constitutional Court or a deputy president designated by the President. The sections and the General Assembly shall take decisions by absolute majority. Commissions may be established to examine the admissibility of the individual applications. Para. 2 TC: The General Assembly shall hear the cases and applications concerning political parties, actions for annulment and objection, and trials where the Constitutional Court acts as the Supreme Court; the sections shall take the decision on individual applications. Para. 5 TC: The formation of the Constitutional Court, trial procedures of the General Assembly and the sections, disciplinary matters of the President, the deputy presidents, and members shall be regulated 
by law; principles of functioning of the Court, formation of the sections and commissions, and the division of labour shall be set out by the internal regulations to be drawn up by the Court."

13. The initial date of 23 September 2012 for allowing constitutional complaints relates to the Transitional Article 18 para. 7 of the Constitutional Amendment Act from 12 September 2010 which provided that the CCT Act should be enacted at the latest within two years and that individual complaints should be allowed after entry into force of the Act. The CCT Act No. 6216 was enacted by Parliament on 30 March 2011 and entered into force on publication in the Official Gazette on 3 April 2011. However, the Transitional Article 1 para. 8 CCT Act No. 6216 provided that the Court may only accept constitutional complaint applications which deal with acts and court judgments which became binding after 23 September 2012. The beginning of the new comprehensive power of the Constitutional Court was therefore fixed by statute. Correspondingly, $\$ 76$ of the Act provided that provisions on constitutional complaint proceedings (\$45-51) did not enter into force until 23 September 2012.

14. Judgment of the Constitutional Court on the constitutionality of the CCT Act No. 6216, E. 2011/59, K. 2012/34 from 1 March 2012.

15. For comprehensive analysis and criticism of the Act before the decision of the Constitutional Court, see Göztepe (2011).

16. See "Anayasa Mahkemesinin Kuruluşu ve Yargılama Usulleri Hakkında Kanun Tasarısı ile İlgili Anayasa Komisyonu Raporu”, 20.

17. See (Zuck 2013, 212 para. 684-712); İnceoğlu (2017, 151-168).

18. See the Judgment Ref. 2013-1430 (İhsan Doğramacı Bilkent Üniversitesi), para. 26: the Constitutional Court holds that $\$ 46(2)$ CCT Act provides for no exception with respect to the legal relationship of legal entities under public law and that standing to lodge a constitutional complaint is to be rejected categorically. Also in Judgment Ref. 2012-22 (Büğdüz Köyü Muhtarlığı), para. 28.In his dissenting opinion, Justice Erdal Tercan stated that a categorical denial of standing to legal entities under public law to lodge a constitutional complaint would necessarily mean a contradiction in constitutional procedural guarantees. Whilst the procedural guarantees in Art. 36 TC can be relied on by "everybody", including legal entities under public law, their exclusion from constitutional complaint proceedings would interrupt the causal link in procedural guarantees and give rise to a constitutional contradiction. It would also impair a constitutional interpretation of guarantees for rights of action.

19. See "Anayasa Mahkemesinin Kuruluşu ve Yargılama Usulleri Hakkında Kanun Tasarısı ile İlgili Anayasa Komisyonu Raporu", 20.

20. Art. 152 para. $1 \mathrm{TC}$ : "If a court before which proceedings are pending believes the provisions of a law or ordinance with the force of law is unconstitutional or, if it takes the view that the assertion of unconstitutionality made by one of the parties is to be taken seriously, then it shall suspend proceedings until a decision from the Constitutional Court has been reached on this point."

21. This was recently the case in proceedings to ban the Refah party. See the decision E. 1997/1 (siyasi parti kapatma) [party prohibition]; K. 1998/1 dated 16.1.1998. Within the framework of these proceedings, the question of the constitutionality of $\$ 103(2)$ of the Act on Political Parties No. 2820 was treated as a "preliminary question" (bekletici sorun) and the question of constitutionality of the norm was answered in the decision E. 1998/2, K. 1998/1 dated 9.1.1998.

22. Cf. inter alia Ref. 2013/695 (Ersin Ceyhan) (excessive duration of proceedings) or 2013/ 1420 (Hidır Memicil); 2012/239 (Ramazan Aras) (unlawfully long custody periods).

23. Ref. 2014/3986 (Yaman Akdeniz ve Diğerleri).

24. Ref. 2014/4705 (YouTube).

25. Inter alia Ref. 2013/7800 (Sencer Başat ve Diğerleri); 2014/4991 (Ahmet Gökhan Rahtuvan).

26. Ref. 2013/409 (Abdullah Öcalan).

27. Ref. 2014/256 (Tuğba Arslan).

28. Art. 149 para. 3 TC: "For the nullity of a constitutional amendment, the prohibition of a party or the declaration of withdrawal of state aid, the decision requires a two-thirds majority of members present." 
29. The decisions on Twitter (Ref. 2014/3986 dated 2.4.2014), YouTube (Ref. 2014/4705 dated 29.5.2014) and in the so-called Sledgehammer case (Balyoz davasi) (Ref. 2013/7800 dated 18.6.2014) were concluded in accordance with this procedure.

30. See also İnceoğlu (2017, 263); Şirin (2015, 256-258); Kanadoğlu (2015, 233-235).

31. The Court's practice has shown that in the first five years after the introduction of the constitutional complaint, the Court endeavoured to publish most decisions in the Official Gazette, making them accessible to a wider public.

32. A second extension of the legal areas were introduced through the Decision of the Council of Ministers No. 2016/8509 (published in the Official Gazette on 9 March 2016, No. 29648).

33. Ümmühan Kaplan vs. Turkey, No. 24240/07 (20.3.2012), para. 63-65; 74-77.

34. Ümmühan Kaplan vs. Turkey, tenor, point 5.

35. Müdür Turgut and Others vs. Turkey, No. 4860/09 (26.3.2013).

36. Müdür Turgut and Others vs. Turkey, para. 55, 57 and 58. On the other hand, the ECtHR stresses explicitly that even after the decision of the Constitutional Court, the road to Strasbourg is open and that the Court reserves the right to judge the efficiency of the new right of recourse for itself (para. 53 and 57). In the case of Ayșe Durusoy and Others vs. Turkey, No. 34600/04 (21.5.2003), the ECHR held that all applications must be rejected as inadmissible due to non-exhaustion of domestic rights of recourse.

37. Ref. 2014/3986 (Yaman Akdeniz ve Diğerleri); 2014/4705 (YouTube); 2013/409 (Abdullah Öcalan); and 2013/1481 (İsa Yağbasan ve Diğerleri).

38. Ref. 2012/1272 (Mustafa Ali Balbay); 2012/849 (Mehmet Haberal); 2013/9894 (Gülser Y1ldırım); 2013/9895 (İbrahim Ayhan); 2014/85 (Kemal Aktaş ve Sema Irmak); and 2014/9 (Faysal Sarıyıldız).

39. Ref. 2013/8463 (Tayfun Cengiz); 2013/8517 (Ertan Rüstem).

40. Ref. 2013/6319 (Cemil Danışman); 2013/293 (Cezmi Demir ve Diğerleri); 2012/848 (Rahil Dink ve Diğerleri); 2013/6585 (Salih Ülgen ve Diğerleri); 2013/2515 (Selahatdin Akgüre ve Diğerleri); 2013/6359 (Deniz Yazıc1); 2012/752 (Serpil Kerimoğlu ve Diğerleri); and 2012/ 850 (Mehmet Ali Emir ve Diğerleri).

41. Ref. 2013/533 (Ercan Kanar).

42. Ref. 2014/6192 (İş Bankası A.Ş.).

43. Ref. 2012/791 (Özkan Şen).

44. Art. 79 para. 1 TC: "Elections shall be held under the general administration and supervision of the judicial organs."

45. E. $1967 / 13$, K. $1969 / 5(14 / 15 / 16.1 .1969)$.

46. E. $1992 / 12$, K. $1992 / 7$ (18.2.1992).

47. Belilos vs. Switzerland, No. 10328/83 (29.4.1988), §64; Findlay vs. the United Kingdom, No. 22107/93, (25.2.1997), §77.

48. Ref. 2013/3912 (İsmail Taşpınar), §30-35, 38, 48.

49. See, for the same argument, İnceoğlu $(2017,213-216)$; Şirin $(2015,94)$.

50. Ref. 2014/5425 (Mansur Yavaş), §31-35; 2014/184 (Nejdet Atalay), §60-63; 2014/2606 (Fatih Poyraz ve Diğerleri), §21-23. With references to ECHR jurisdiction: Molka vs. Poland, No. 56550/00; Malarde vs. France, No. 46813/99; Clerfayt, Legros vs. Belgium, No. $10650 / 83$

51. Ref. 2017/20127 (Nurullah Efe ve Halkın Kurtuluşu Partisi), §16.

52. Ref. 2014/13675 (Mustafa Ekici); 2014/11717 (Ahmet Çalışkan).

53. Ref. 2014/11268 (Liberal Demokrat Parti); 2014/11368 (Mahmut Tanal); 2014/11438 (Mahmut Tanal (2)); 2014/13625 (Sabri Ergül); 2014/13634 (Atilla Kart ve Cumhuriyet Halk Partisi).

54. Ref. 2014/8842 (Büyük Birlik Partisi ve Diğerleri).

55. Ref. 2015/6723 (Atila Sertel); 2015/8818 (Oğuz Oyan). Both decisions of the General Assembly and published in the Official Gazette on 7 October 2015. For further decisions in line with the argumentation of these, see 2014/3531 (Kanal Beyaz Televizyon Radyo Yay); 2015/6402 (Turgut Yenilmez); 2015/8764 (Vatan Partisi).

56. Ref. 2015/6723 (Atila Sertel), §39-40; 2015/8818 (Oğuz Oyan), §27-28. 


\section{References}

Act on the Structure and the Competences of the Constitutional Court of Turkey (law $\mathrm{N}^{\circ} 6216$, adopted 30 March 2011). http://www.venice.coe.int/webforms/documents/?pdf=CDL-REF (2011)047-e

Adalet ve Kalkınma Partisi Grup Başkanı İstanbul Milletvekili Recep Tayyip Erdoğan ve 264 Milletvekilinin; 7/11/1982 Tarihli ve 2709 Sayılı Türkiye Cumhuriyeti Anayasasının Bazı Maddelerinde Değișiklik Yapılması Hakkında Kanun Teklifi ve Anayasa Komisyonu Raporu [The application for constitutional amendment and the report by the Parliamentary Constitutional Commission], (2/656), TBMM (S. Sayıs1: 497), Dönem: 23 Yasama Y1lı: 4. https://www.tb $\mathrm{mm}$. gov.tr/sirasayi/donem23/yil01/ss497.pdf

Anayasa Mahkemesinin Kuruluşu ve Yargılama Usulleri Hakkında Kanun Tasarısı ile İlgili Anayasa Komisyonu Raporu [Report by the Constitutional Commission to the Draft Law on the Establishment and Rules of Procedure of the Constitutional Court], TBMM 23. Dönem, Yasama Y1l: 5, S. Say1s1: 696. https://www.tbmm.gov.tr/sirasayi/donem23/yil01/ss696.pdf

Armağan, Servet. 1971. "Federal Almanya'da Anayasa Şikayeti [Constitutional Complaint in the Federal Republic of Germany].” Mukayeseli Hukuk Araştırmaları Dergisi 7: 53-75.

Gören, Zafer. 1994. "Anayasa Mahkemesi’ne Kişisel Başvuru [Individual Complaint to the Constitutional Court]." Anayasa Yargisı 11: 97-134.

Göztepe, Ece. 1998. Anayasa Şikayeti [Constitutional Complaint]. Ankara: Ankara Üniversitesi Hukuk Fakültesi Yayınları.

Göztepe, Ece. 2010. "Eine Analyse der Verfassungsänderungen in der Türkei vom 7. Mai 2010: Ein Schritt in Richtung mehr Demokratie? [An Analysis of the Constitutional Amendments of 7th May 2010: A step towards more democracy?]" Europäische Grundrechte Zeitschrift 2223: $685-700$.

Göztepe, Ece. 2011. “Türkiye'de Anayasa Mahkemesi'ne Bireysel Başvuru Hakkının (Anayasa Şikâyeti) 6216 Sayılı Kanun Kapsamında Değerlendirilmesi [The Evaluation of The Right of Individual Complaint within the Framework of the Act No. 6216]." Türkiye Barolar Birliği Dergisi 95: 13-40.

Grabenwarter, Christoph. 2009. Europäische Menschenrechtskonvention [European Convention on Human Rights]. München: C.H.Beck.

İnceoğlu, Sibel. 2017. Anayasa Mahkemesi'ne Bireysel Başvuru. Türkiye ve Latin Amerika Modelleri [Constitutional Complaint to the Constitutional Court. The Models in Turkey and Latin America]. İstanbul: XII Levha.

Kanadoğlu, Korkut. 2015. Anayasa Mahkemesi'ne Bireysel Başvuru [Constitutional Complaint to the Constitutional Court]. İstanbul: XII Levha.

Pekcanıtez, Hakan. 1995. "Mukayeseli Hukukta Medeni Yargıda Verilen Kararlara Karşı Anayasa Şikayeti [Constitutional Complaint Against Civil Law Decisions in Comparative Law]." AnayasaYargisl 12: 257-287.

Recommendation $\operatorname{Rec}(2004) 6$ of the Committee of Ministers to member states on the improvement of domestic remedies (adopted by the Committee of Ministers on 12 May 2004). https:// search.coe.int $/ \mathrm{cm} /$ Pages/result_details.aspx?ObjectID $=09000016805 \mathrm{dd} 18 \mathrm{e}$

Sabuncu, Yavuz. 1982. "Federal Almanya'da Anayasa Şikayeti [Constitutional Complaint in the Federal Republic of Germany]." Ankara Üniversitesi Siyasal Bilgiler Fakültesi Dergisi 37: $139-152$.

Sabuncu, Yavuz. 1984. "Alman Anayasa Yargısında Geçici Tedbir Kararı [Interim Measures in German Constitutional Review].” Amme İdaresi Dergisi 17: 76-85.

Schilling, Theodor. 2010. Internationaler Menschenrechtsschutz [International Human Rights Protection]. Tübingen: Mohr Siebeck.

Şirin, Tolga. 2015. Anayasa Mahkemesi Kararları Işı̆̆ı̆nda Bireysel Başvuru Hakkı [The Right to Constitutional Complaint in Light of the Jurisdiction of the Constitutional Court]. İstanbul: XII Levha.

Statistics of the ECtHR for the period 1959-2016. http://www.echr.coe.int/Documents/Stats_viola tion_1959_2016_ENG.pdf

Türkiye, Barolar Birliği. 2007. Türkiye Cumhuriyeti Anayasa Önerisi. Geliştirilmiş Gerekçeli Yeni Metin [Union of Turkish Bar Associations, Draft Constitution for the Republic of Turkey. A Comprehensive and Reasoned New Text]. Ankara: Türkiye Barolar Birliği Yayınları.

Zuck, Rüdiger. 2013. Das Recht Der Verfassungsbeschwerde [The Right of Constitutional Complaint]. München: C.H. Beck. 